
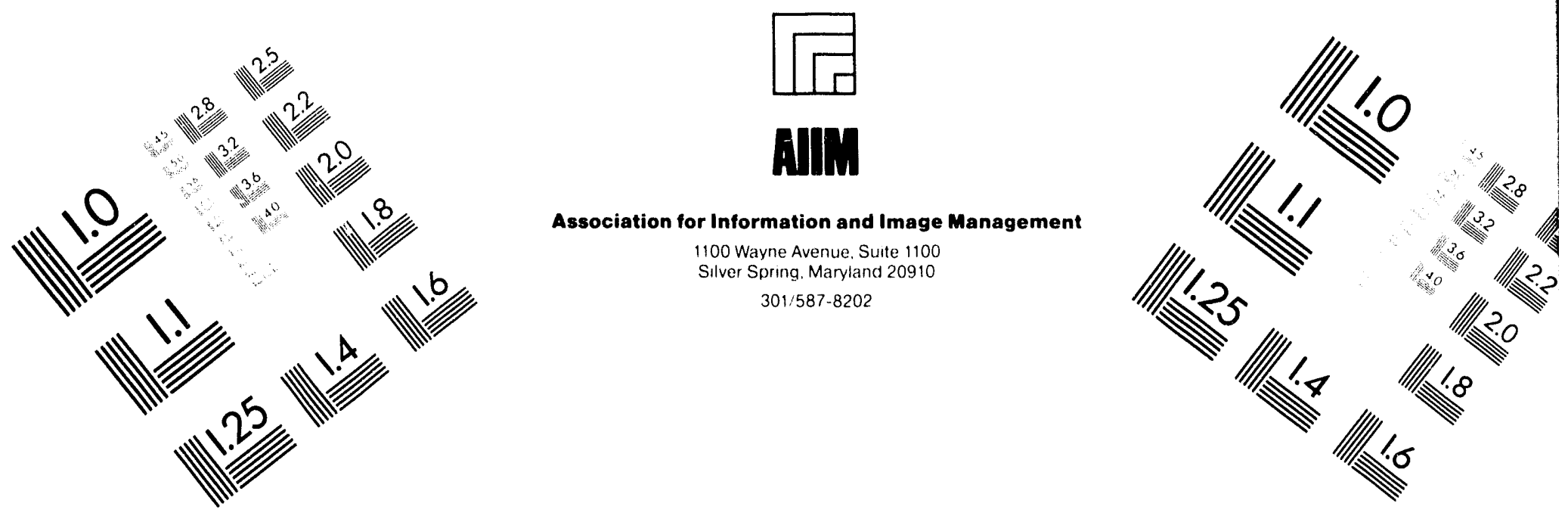

\title{
Centimeter
}

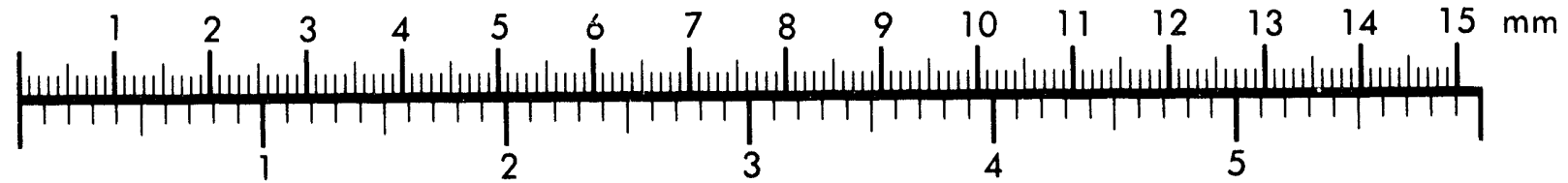

Inches
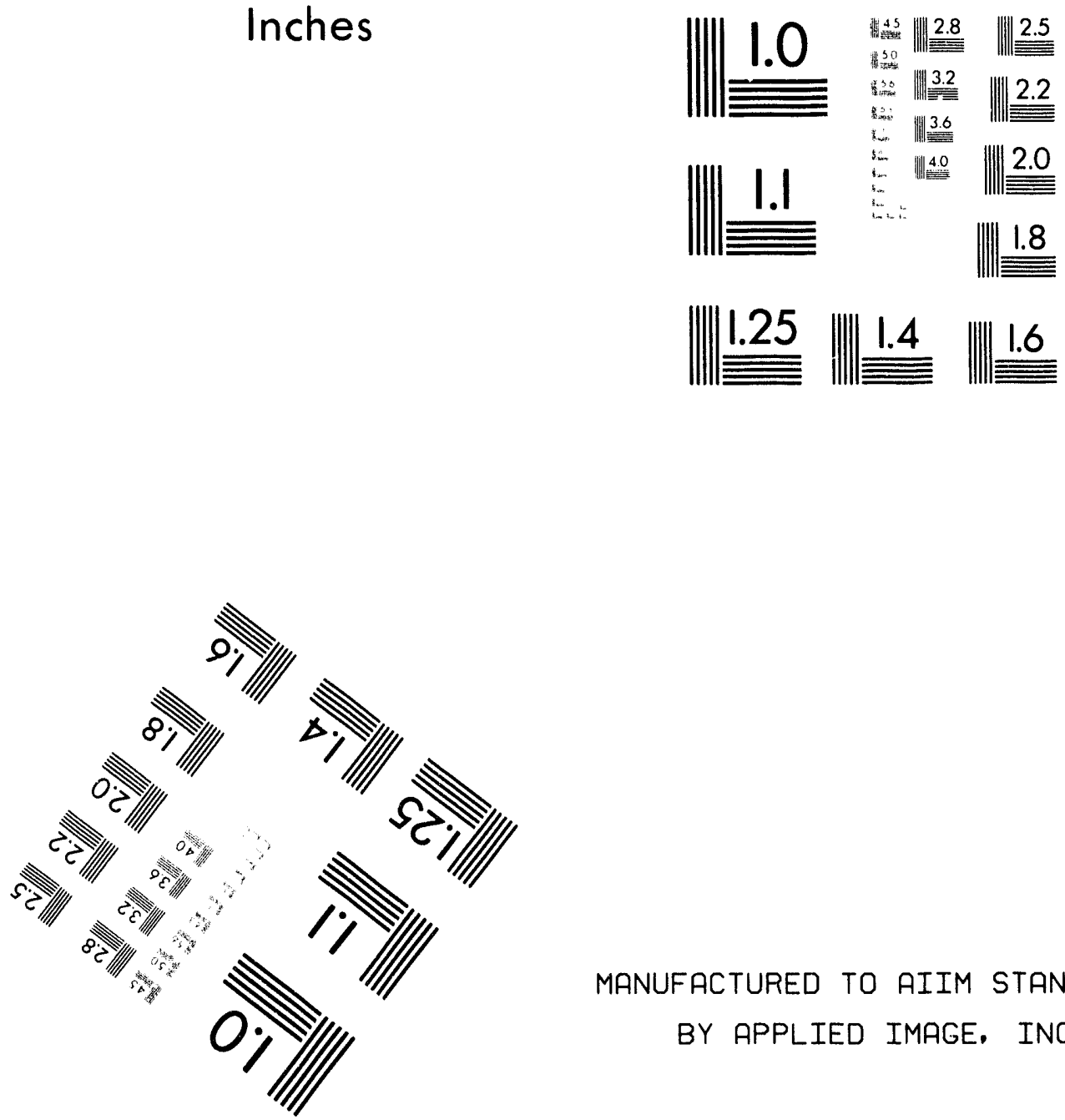

MANUFACTURED TO AIIM STANDARDS

BY APPLIED IMAGE, INC.

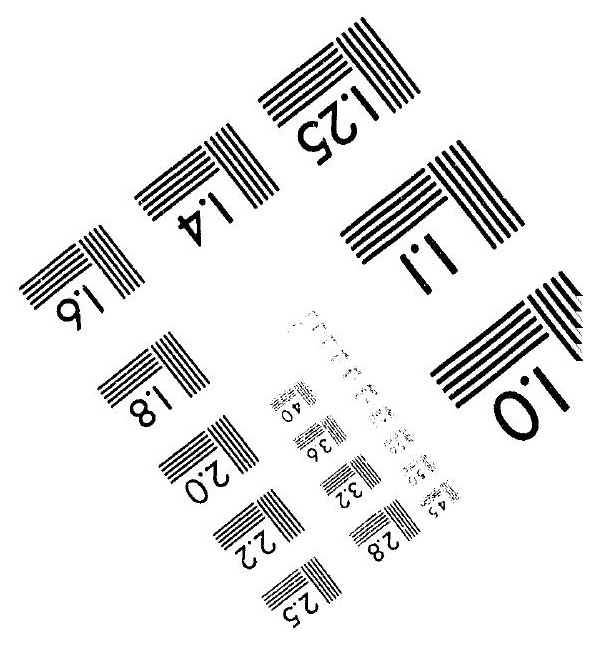



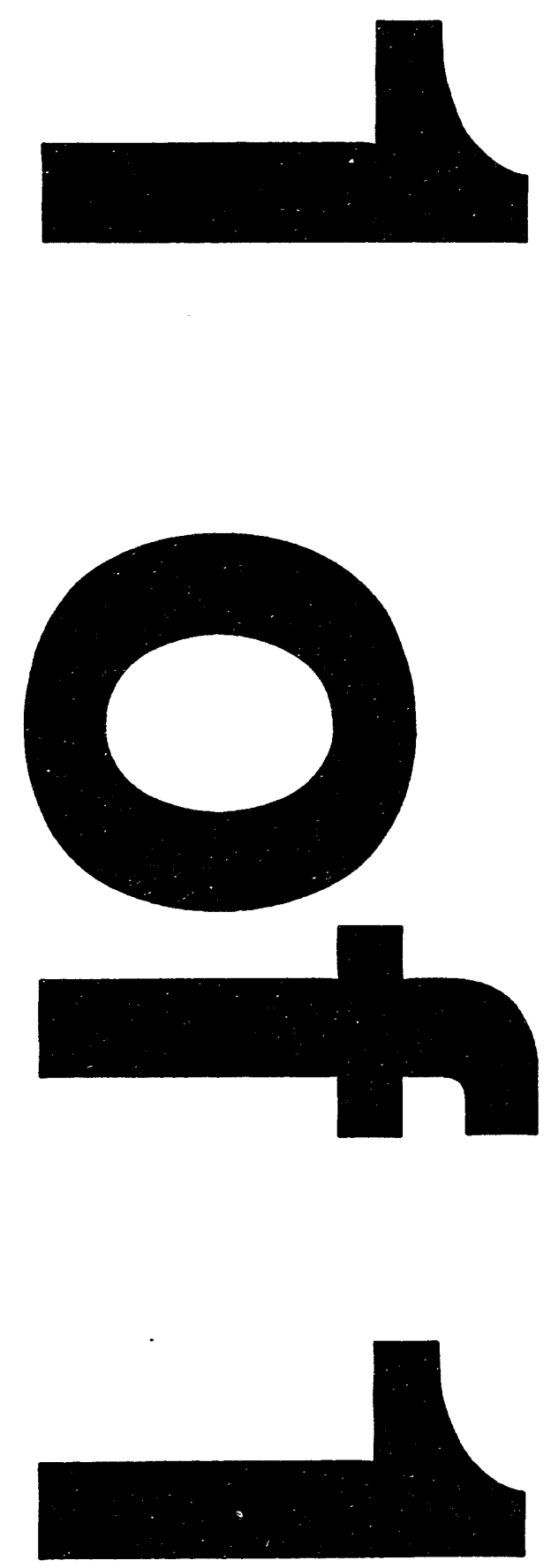


\section{SAFETY ASSESSMENT FOR THE ABOVE GROUND STORAGE OF CADMIUM SAFETY AND CONTROL RODS AT THE SOLID WASTE MANAGEMENT FACILITY (U)}

Author:

K.W. Shaw

November, 1993

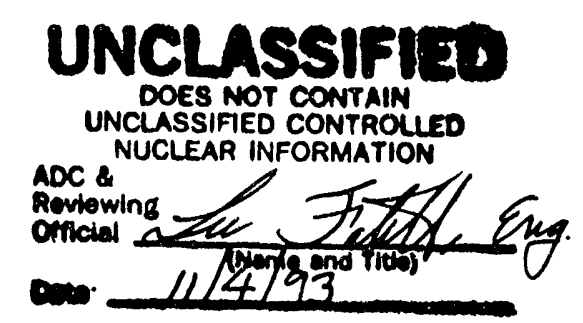

Westinghouse Savannah River Company Savannah River Technology Center Aiken, SC 29808

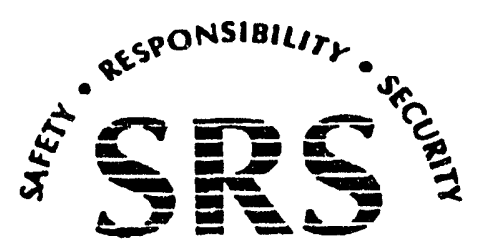

PREPARED FOR THE U.S. DEPARTMENT OF ENERGY UNDER CONTRACT NO. DE-AC09-89SR 18035 


\section{DISCLAIMER}

This report was prepared by Westinghouse Savannah River Company (WSRC) for the United States Department of Energy under Contract No. DE-AC09-89SR18035 and is an account of work performed under that contract. Neither the United States Department of Energy, nor WSRC, nor any of their employees makes any warranty, expressed or implied, or assumes any legal liability or responsibility for the accuracy, completeness, or usefulness, of any information, apparatus, or product or process disclosed herein or represents that its use will not infringe privately owned rights. Reference herein to any specific commercial product, process, or service by trademark, name, manufacturer or otherwise does not necessarily constitute or imply endorsement, recommendation, or favoring of same by WSRC or by the United States Government or any agency thereof. The views and opinions of the authors expressed herein do not necessarily state or reflect those of the United States Government or any agency thereof. 

Key Words: TRU Pads
Casks
SWMF
Burial Grounds
Cadmium
Safety Rods
Control Rods

Retention: Lifetime

\title{
SAFETY ASSESSMENT FOR THE ABOVE GROUND STORAGE OF CADMIUM SAFETY AND CONTROL RODS AT THE SOLID WASTE MANAGEMENT FACILITY (U)
}

\author{
Author:
}

K.W. Shaw

November, 1993 
Project: Cadmium Safety and Control Rod Storage

Document: WSRC-TR-93-597

Title: $\quad$ Safety Assessment For The Above Ground Storage Of Cadmium Safety And Control Rods At The Solid Waste Management Facility (SWMF) (U)

Task Plan: $\quad$ SRT-EAG-93-8005

Approvals:

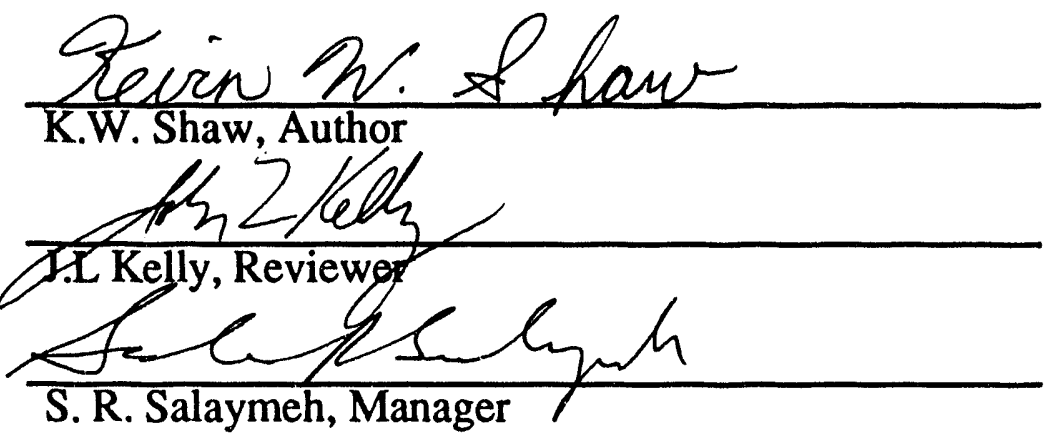

$\frac{11-4-93}{\text { Date: }}$
$\frac{11-4-93}{\text { Date: }}$
$\frac{11 / 4 / 93}{\text { Date: }}$




\begin{abstract}
The mission of the Savannah River Site is changing from radioisotope production to waste management and environmental restoration. As such, Reactor Engineering has recently developed a plan to transfer the safety and control rods from the C, K, L, and P reactor disassembly basin areas to the Transuranic (TRU) Waste Storage Pads for long-term, retrievable storage. The TRU pads are located within the Solid Waste Management Facilities at the Savannah River Site.

An Unreviewed Safety Question (USQ) Safety Evaluation [1] has been performed for the proposed disassembly basin operations phase of the Cadmium Safety and Control Rod Project. The USQ screening identified a required change to the authorization basis; however, the Proposed Activity does not involve a positive USQ Safety Evaluation. A Hazard Assessment [2] for the Cadmium Safety and Control Rod Project determined that the above-ground storage of the cadmium rods results in no change in hazard level at the TRU pads.
\end{abstract}

A Safety Assessment that specifically addresses the storage (at the TRU pads) phase of the Cadmium Safety and Control Rod Project has been performed. Results of the Safety Assessment support the conclusion that a positive USQ is not involved as a result of the Proposed Activity. 


\section{Table of Contents}

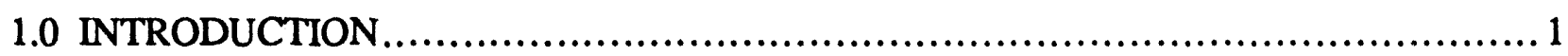

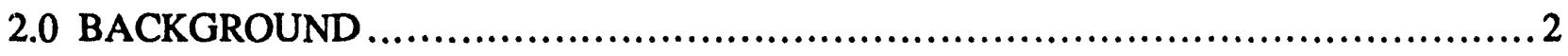

3.0 ASSESSMENT METHODS AND ASSUMPTIONS ................................. 2

3.1 Physical Descriptions .............................................................. 2

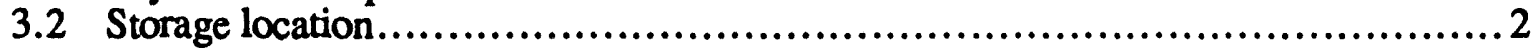

3.3 Radioisotope Content Determination ........................................... 3

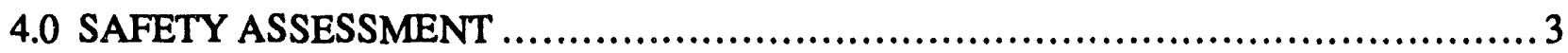

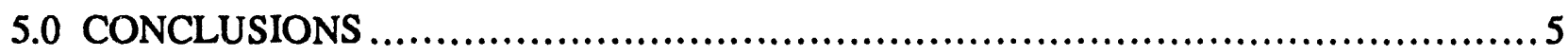

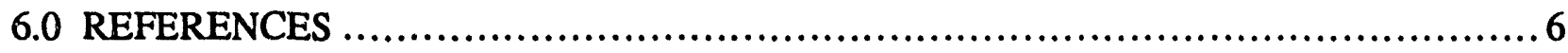




\title{
LIST OF ACRONYMS AND ABBREVIATIONS
}

\author{
DOE Department of Energy \\ PA Proposed Activity \\ RCRA Resource Conservation and Recovery Act \\ SWMF Solid Waste Management Facility \\ TRU Transuranic \\ USQ Unreviewed Safety Question \\ WSRC Westinghouse Savannah River Company
}




\subsection{INTRODUCTION}

As the Savannah River Site (SRS) mission continues to change from radioisotope production to waste management and environmental restoration, many of the components associated with the reactor facilities will be stored or discarded as radioactive and/or hazardous waste material. Reactor Engineering has developed a preliminary plan [6] for transferring the cadmium safety and control rods from the $\mathrm{C}, \mathrm{K}, \mathrm{L}$, and $\mathrm{P}$ reactor disassembly basin areas to the transuranic (TRU) waste storage pads for retrievable, above-ground storage. The TRU pads are located within the Solid Waste Management Facilities (SWMF) at SRS.

The proposed Cadmium Safety and Control Rod Project specifies the following actions:

- Rods are transferred from reactors to their respective disassembly basin

- The aluminum ends of the cadmium rods are cut off to fit within the proposed storage casks (this step is conducted in the machine basin and includes the interim storage, handling, and transfer of uncut and cut rods and ends)

- The cut rods and ends are transferred to separate storage casks (this step includes placement and removal of storage casks in basin transfer pits, and handling and transfer of cut rods and ends)

- The cut cadmium rods and ends are stored (within casks) on site at the TRU waste storage pads.

A USQ safety evaluation has been performed for the disassembly basin operations phase of the proposed Cadmium Safety and Control Rod Project [1]. Although the USQ screening identified a required change to the authorization basis, the proposed activity does not involve a positive USQ safety evaluation. A hazard assessment [2] concluded that the cadmium rods constitute a Category 3 hazard. A Category 3 hazard, the lowest of the 3 hazard categories, is defined as a hazard with the potential for only significant localized consequences (low hazard). High-level TRU waste is already being stored at the TRU waste pads. Thus, the TRU pads will not experience an increase in hazard category because of the cadmium rods.

This report specifically addresses the safety significance of storing the cadmium safety and control rods at the TRU pads (i.e., the storage phase of the proposed Cadmium Safety and Control Rod Project). 


\subsection{BACKGROUND}

The safety and control rods used in the reactors utilized cadmium as a neutron absorber and type 304 stainless steel as an encapsulation medium. Cadmium is a hazardous waste. A hazardous waste is defined as a waste which, because of its toxicity, physical/chemical state, or infectious characteristics, may pose a substantial hazard to human health or the environment when improperly managed. As components located within the reactor tank, the stainless steel sheathing of the cadmium rods became activated through neutron absorption and now produce gamma radiation through the decay of Cobalt 60 . Therefore, the cadmium rods are classified as both radioactive and hazardous (i.e., mixed) waste. The rods will be placed in a modified EP85 cask [7] and stored on the uncovered TRU pads (pads 7-13) at the SWMF. A significant percentage of TRU waste is also classified as hazardous waste. TRU waste storage pads 6-13 are currently under an interim status permit allowing the storage of both TRU and non-TRU hazardous waste on the pads. For this safety evaluation, the Proposed Activity (PA) is defined as the storage of the cadmium safety and control rods at the TRU pads. The current authorization basis, the Burial Ground Operations SAR [5], does not address the storage of cadmium safety and control rods on the TRU pads.

\subsection{ASSESSMENT METHODS AND ASSUMPTIONS}

The assessment of storing cadmium safety and control rods at the TRU pads will be based on the following:

\subsection{Physical Descriptions:}

The safety and control rods used in the SRS reactors utilized cadmium as a poison and type 304 stainless steel as an encapsulation medium. The cadmium safety and control rods are approximately 250 inches in length and approximately 1.00 inch in diameter [6]. The cadmium plating covers approximately 14 feet of the total rod length; the remaining 7.5 feet (approximate) consists of only the aluminum rod and stainless steel encapsulation jacket [6].

The EP85 shipping cask will be modified [7] and used to store the cadmium safety and control rods at the TRU pads. The EP85 cask weighs approximately 75 tons empty and approximately 85 tons when loaded with 856 rods. The cask has an 8.5 inch thick lining of lead shielding, and an internal length of 15 feet, which provides sufficient volume to contain up to 860 irradiated rods [6]. The use of this cask, however, will require the cutting/shearing of the cadmium rods at 14-15 feet (from the top of the rod). This will leave the cadmium portion (the bottom portion) of the approximately 21 foot rod intact. The non-radioactive rods and the top of the cut rods (the ends) will be placed in separate storage casks [6].

\subsection{Storage location:}

The cadmium rods will be stored at the uncovered TRU pads (pads 7-13) until a final disposal facility has been identified. The final disposal facility is expected to be the hazardous waste/mixed waste storage vaults [6]. This safety assessment, however, specifically addresses cadmium rod storage at the TRU pads. 


\subsection{ASSESSMENT METHODS AND ASSUMPTIONS (CONT.)}

\subsection{Radioisotope Content Determination:}

The determination of a radiation source term is required to assess the safety impact on the TRU pads as a result of storing the cadmium safety and control rods. This assessment will be based on Co-60 being the only radioactive isotope of any real concern [4]. Conservatively applying the worst case activation estimate of about $9 \mathrm{Ci}$ per rod [4] to 1000 cadmium rods yields a maximum of 9,000 Curies of Co-60 [2].

\subsection{SAFETY ASSESSMENT}

The safety assessment of retrievable, above-ground storage of cadmium rods on the TRU pads is documented below as a USQ Safety Evaluation [9], Procedure 3.10, Rev. 1. The USQ screening has not been included, because it has already been concluded in Section 2.0 of this report that a change to the authorization basis is required, thereby requiring a USQ Safety Evaluation.

\section{A.4 USQ Safety Evaluation}

A.4.1 Could the proposed activity increase the probability of occurrence or the consequences of an accident or malfunction of equipment important to safety previously evaluated in the facility Authorization Basis?

$$
\text { [X] No [ ] Yes }
$$

\section{Reasons/References:}

The addition of the cask-contained cadmium rods will not significantly increase the probability of occurrence or the consequences of an accident previously evaluated in the facility authorization basis. In addition, the facility authorization basis [5] does not identify any equipment important to safety. Therefore, the PA does not increase the probability of occurrence or the consequences of a malfunction of equipment important to safety previously evaluated in the facility authorization basis.

The proposed activity, above-ground storage of cadmium rods, is equivalent to activities currently authorized for TRU waste at the TRU pads. The Burial Ground Operations SAR [5], Section 4.2.2.1 states ... "Solid radioactive waste at SRP is segregated into five categories according to the kinds and amounts of radionuclides in the waste. Two categories, transuranic (TRU) and mixed waste, are stored on ground level concrete pads (retrievable)." The cadmium rods are classified as both radioactive and hazardous (i.e., mixed) waste.

The $\mathrm{ri}$ ological inventory of the cadmium rods is sig. ificantly less than the total radiological inventory of the TRU waste presently stored at the TRU pads [5], Section 4.2.2, and the cadmium rods contain no fissionable material. Additionally, the relative radioactive hazard posed by the cadmium safety rods is low because the Co- 60 material is bound within the activated metal rods, a stainless steel jacket encapsulates the rods, and the rods are encapsulated within the EP85 storage cask. The EP85 cask is made up of $1 / 2$ inch thick steel exterior panels lined with 8.5 inches of 
lead shielding, $1 / 4$ inch thick steel interior panels, weighs approximately 75 tons when empty, and will be welded along its entire seal length to provide water-proof macro-encapsulation for the cadmium rods [6]. Clearly, the EP85 cask is a much more robust storage container than the 55 gallon drums that contain the majority of the waste presently stored on the TRU pads.

Therefore, given the relatively minor addition to the total radionuclide inventory presently stored at the TRU pads, the macro-encapsulation of the radioactive material, and the favorable structural characteristics of the casks as compared to 55 gallon drums, neither the likelihood or the consequences of an accident previously evaluated in the Burial Ground SAR [5] will be increased by the Proposed Activity.

\section{A.4.2 Could the proposed activity increase the possibility for an accident or malfunction of equipment important to safety of a different type than any previously evaluated in the facility Authorization Basis?}

$$
\text { [X] No [ ] Yes }
$$

\section{Reasons/References:}

The PA will not increase the possibility for an accident or malfunction of equipment important to safety of a different type than any previously evaluated in the facility Authorization Basis.

Irradiated cadmium rods contain Co-60 and other activation products [4]. However, Co-60 is the only radioactive isotope of any real concern [4]. Conservatively applying the worst case activation estimate of about $9 \mathrm{Ci}$ per rod [4] to 1000 cadmium rods yields a maximum of 9,000 Curies of Co60 [2]. A heat transfer analysis has been performed on the rods placed in the EP85 storage cask [3]. This analysis demonstrates that the peak temperature attained by the rods stored within the cask is below the melting points of the materials that comprise both the cadmium rods and the storage cask. Therefore, melting of the rods in the cask or the cask itself cannot occur.

The cadmium rods are cut with a saw to enable their storage within the EP85 cask. The cutting, however, is performed prior to placing the rods within the cask and shipping the cask to the SWMF for storage on the TRU pads. The cadmium portion of the rod is uncut, however, and remains encapsulated within the stainless steel jacket of the rod. Furthermore, the cask will be sealed with a weld after all the rods have been placed in it. Rod encapsulation and sealing of the cask prevents ground water intrusion and subsequent contamination by cadmium.

A significant percentage of TRU waste already stored at the TRU pads is also classified as hazardous waste. TRU waste storage pads 6-13 are currently under an interim status permit that allows the storage of both TRU and non-TRU hazardous waste on the pads. Storage of the mixed waste cadmium rods at the TRU pads, therefore, does not introduce a new or different type of material to the TRU pads. 
A.4.3 Could the proposed activity decrease the Margin of Safety as defined in the Technical Safety Requirements (TSRs) of the Authorization Basis?

Reasons/References

[X] No [ ] Yes

The proposed activity does not violate Technical Safety Requirements.

The maximum total radionuclide inventory for the cadmium rods is estimated at 9,000 Curies of Co-60 [2]. This radionuclide inventory is well below the Technical Standard limits of 60,000 curies per year for Co-60 and 40,000 curies per year for induced activity from radionuclides with half-lives greater than 1 year [8].

If any question in A.4.1 - A.4.3 is answered as "Yes", an Unreviewed Safety Question (USQ) is involved. Proceed to Pat III of this Form to complete the USQ Safety Reviews.

Is a positive USQ safety evaluation involved?

[X] No [ ] Yes

\subsection{CONCLUSIONS}

The conclusion of the USQ Safety Evaluation presented in Section 4.0 of this report is that a positive USQ Safety Evaluation is not involved. Therefore, in accordance with Section 7.2 of the Site Facility Safety Analysis Manual [10], the required SAR changes will not prevent the implementation of the Proposed Activity and can be made subsequent to implementation of the Proposed Activity. 


\subsection{REFERENCES}

1. Cadmium Safety Rod USQ, Transmittal, SRT-RST-930347, dated September 30, 1993.

2. Cadmium Safety Rod Project Hazard Analysis Documentation, SRT-RST-930348, dated October 21, 1993.

3. Kalinich, D.A., to McInnis, S.H., Results of EP 85 Shipping Container Analysis (U), SRTRST-930344, dated September 29, 1993.

4. Baumann, N.P, to Buckner, M.R., Residual Gamma Activity in Cadmium Rods (U), SRTAPG-930079, dated July 16, 1993.

5. Hurrell, S.J., et al, Safety Analysis - 200 Area Savannah River Plant Burial Ground Qperations, DPSTSA-200-10 SUPP 8, E.I. du Pont de Nemours and Co., October 1988.

6. WSRC-TR-y 3-42-062, Revision 0 (draft), Cadmium Control and Safety Rod Disposal Plan (U), Westinghouse Savannah River Company, Aiken, SC, September 21, 1993.

7. PMT 93-1081, Plant Modification Traveler, Westinghouse Savannah River Company, August 1993.

8. WSRC-TN-06, Revision 1, Management of Radioactive Waste at the SRS Storage/Disposal Facilities 643-7G, 643-29G, 709-2G, June 15, 1990.

9. WSRC Administrative aid Procedural Controls System for SRS Reactor and Non-Reactor Nuclear Facilities (U), Procedure Manual 11Q, Westinghouse Savannah River Company, Savannah River Site, Aiken, SC 29808.

10. Facility Safety Analysis Manual (U), Procedure Manual 9Q, Westinghouse Savannah River Company, Savannah River Site, Aiken, SC 29808 

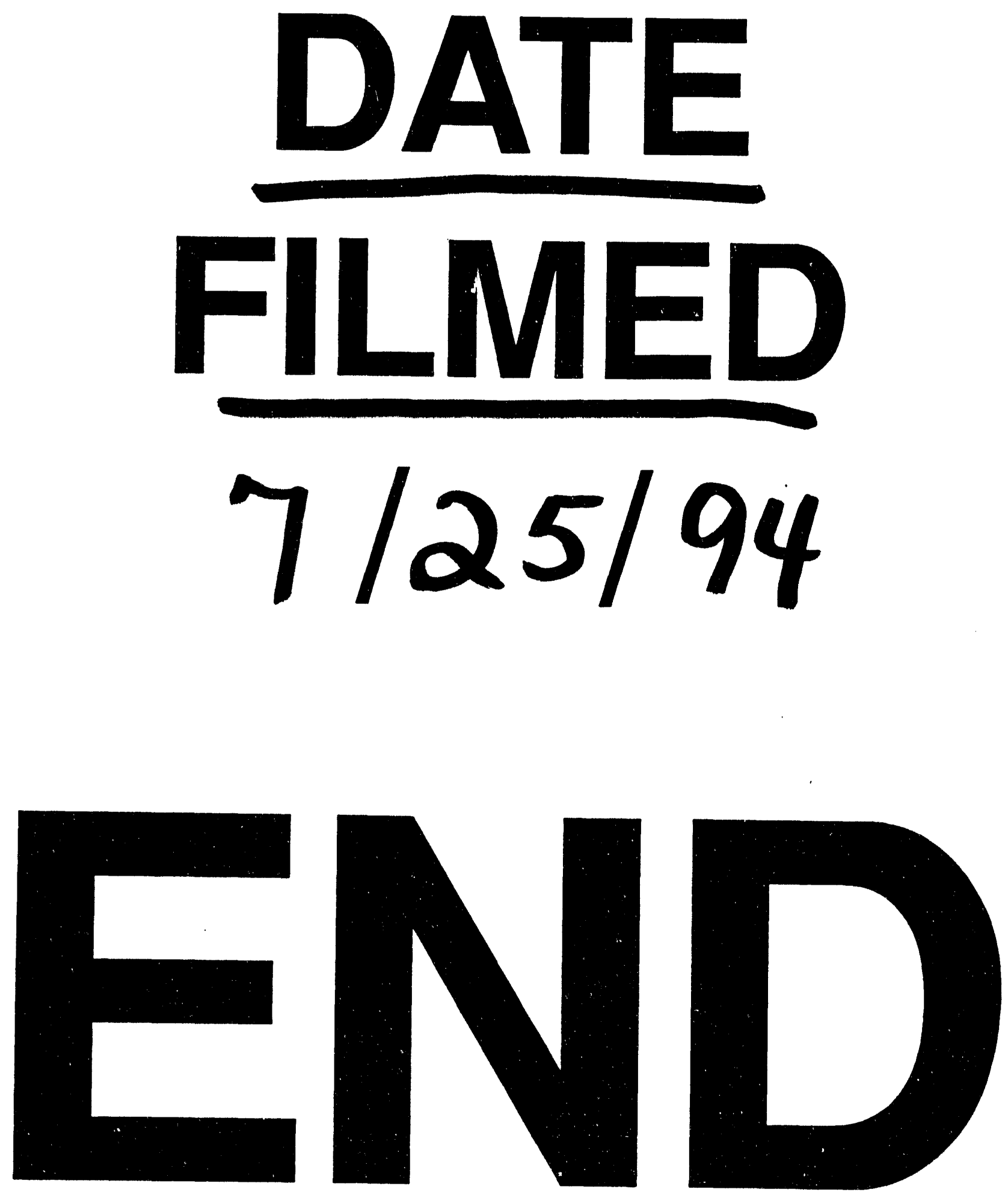
